\title{
The influence of intellectual capital and corporate governance on financial performance of Islamic banks
}

\author{
Rifqi Muhammad, Muhammad Aldino Mangawing, Selfira Salsabilla \\ Department of Accounting, Universitas Islam Indonesia, Yogyakarta
}

\author{
Article History \\ Received : 13 July 2020 \\ Revised : 13 September 2020 \\ Accepted : 11 October 2020 \\ Published : 11 January 2021

\section{Keywords:} \\ Intellectual capital, corporate \\ governance, Islamic banks, financial \\ performance, Sharia Supervisory \\ Board (SSB) \\ DOI: \\ https://doi.org/10.20885/JEKI.vol \\ 7.iss1.art6
}

\section{JEL Classification:}

G21, G32, G38

Corresponding author:

rifqimuhammad@uii.ac.id

\section{Author's email:}

15312466@students.uii.ac.id

selfirasalsabilla@uii.ac.id

\section{Paper type:}

Research paper

Cite this article:

Muhammad, R., Mangawing, M.A., \& Salsabilla, S. (2021). The influence of intellectual capital and corporate governance on financial performance of Islamic banks. Jurnal Ekonomi dan Keuangan Islam, 7(1), 77-91. https://doi.org/10.20885/JEKI.vol7 .iss1.art6

\begin{abstract}
Purpose - This study aims to analyze the effect of intellectual capital, independent directors, academic directors, and sharia supervisory boards on the financial performance of Islamic banks. The selection of samples observation based on the database of Best Islamic Financial Institutions Award, includes Afghanistan, Algeria, Bahrain, Bangladesh, Brunei Darussalam, Egypt, Indonesia, Jordan, Kazakhstan, Kuwait, Lebanon, Malaysia, Maroko, Nigeria, Oman, Pakistan, Palestine, Qatar, Saudi Arabia, Singapore, South Africa, Sri Lanka, Thailand, Tunisia, Turkey, and Uni Emirate Arab.
\end{abstract}

Methodology - This study uses a sample of 20 Islamic banks in several countries which received the "Best Islamic Financial Institutions Award 2018" by Global Finance Magazine and has published financial reports for the period of 2013-2017. This study adopted panel regression analysis and utilized the Random Effect Model.

Findings - The results of the study prove that intellectual capital has a positive effect on financial performance. While independent directors, academic directors, and the Sharia Supervisory Board (SSB) have no effect on the financial performance of Islamic banking companies. These results indicate that intellectual capital is a force for Islamic banking to increase company value through financial performance. While the factors related to corporate governance tend to reduce performance due to several limitations for management in carrying out its operational activities.

Research limitations - this study has a limitation in using Islamic banking data from various countries with backgrounds that are certainly different from one another which might be bias.

Practical implications - This study suggest that management needs to allocate its resources to provide guidance and development of human resources through regular training in the field of figh muamalah, contemporary Islamic banking products and services, effective business communication, as well as extensive market knowledge to anticipate the competition in ways that are in accordance with the principles of sharia.

Originality - This research fills a research gap in investigating the nexus of intellectual capital and corporate governance mechanism on Islamic banking performance which has not been discussed in previous papers, particularly using Islamic banking in several countries that are committed to develop the Islamic financial industry.

\section{Introduction}

The development of the Islamic finance industry has grown modestly in recent years due to large investments in the halal infrastructure and sukuk sectors, mainly through the use of digital 
platforms for all its products and services. The Islamic Financial Services Industry Stability Report 2018 published by the Islamic Financial Service Board (IFSB) stated that the growth of Islamic financial industry assets has grown very rapidly by more than USD 2 billion or $8.3 \%$ higher than the previous two years within the areas of banking, takaful, and capital markets (IFSB, 2018)

Figure 1 provides information on global Islamic financial assets. The figure shows that the Islamic finance industry has grown relatively slowly in the last 3-4 years. In 2013-2014 the Islamic financial industry could grow above $5 \%$. However, recently it could only grow around $2 \%$ which is strongly driven by the growth of the sukuk market, while the growth of Islamic banking market is relatively stagnant. This development is certainly a concern for actors in the Islamic financial industry to find causes and solutions to the conditions that have taken place in recent years. Two things that are considered capable of accelerating the growth of the Islamic financial industry in the future are the standardization of Islamic financial products and services and a more optimal use of information technology (Standard\&Poor's, 2018).

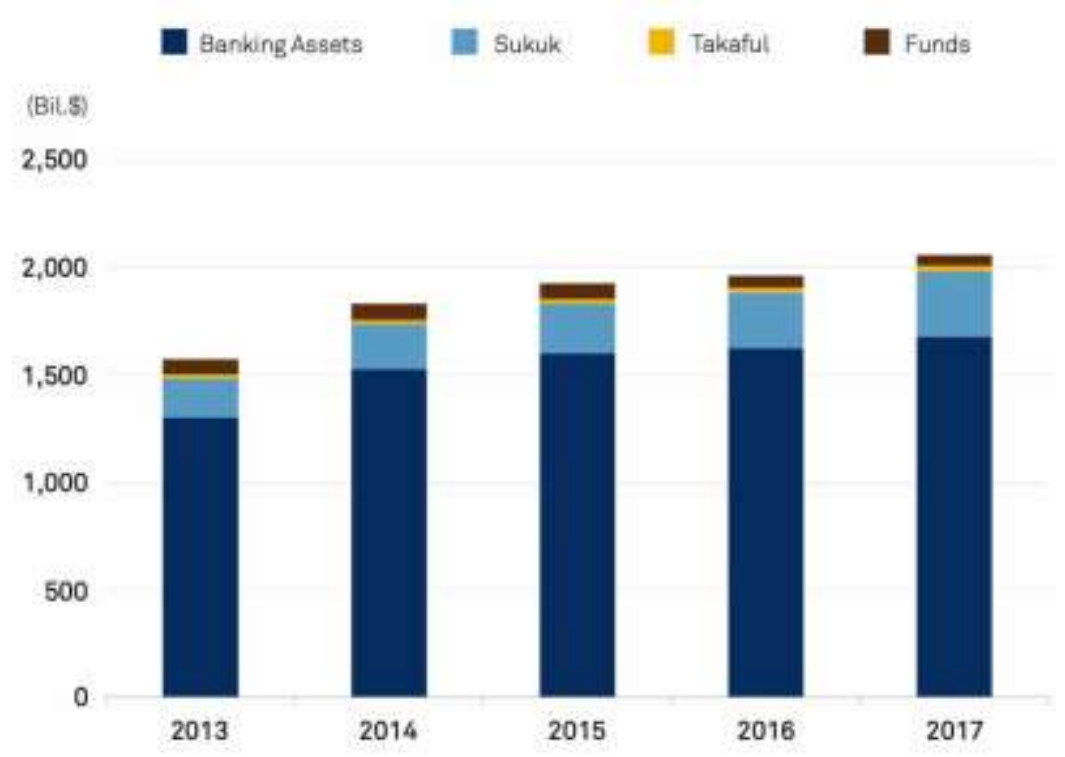

Source: (Standard \& Poor's, 2018)

Figure 1. Assets of Global Islamic Finance

Standardization of Islamic financial products and services is more directed at sukuk products which currently tend to use a fixed income sharing model rather than fluctuating profitsharing. This is because investors feel less comfortable using Profit-Loss-Sharing (PLS) model for it is relatively riskier. Optimizing the use of technology is the focus of service development in the Islamic banking sector, considering the challenges brought by the emergence of financial technology (fintech) platform which could give an impact on the decline in the Islamic banking market which has a relatively similar market segment.

Based on PriceWaterhouseCooper (PwC) data on the Digital Banking Consumer Survey (2018), it shows that more banks that provide digital services, including providers of fintech applications without offices, will affect the future of the global banking market. No exception, Islamic banks will be greatly affected if they are not quick to anticipate this condition. Hence, today we can see some international-scale Islamic banking that began to establish special divisions of digital services such as Meem Digital Banking of Gulf International Bank in Bahrain and Saudi Arabia, Albaraka in Germany and other European countries with a large Muslim community (Research\&Markets, 2020).

Meanwhile, the 2019 Global Islamic Finance Market Report notes that Islamic banking has contributed USD 1.72 Trillion or $71 \%$ of the total global Islamic financial industry. Commercial Islamic banking remains a major contributor to the growth of this sector. There were 505 Islamic bank units in 2017, including 207 Islamic windows. Islamic banking in general is considered to 
have two advantages compared to conventional banking. Firstly, Islamic banks are bound by higher moral standards. The management of Islamic banks is considered more prudent and does not take excessive bonuses for management. Secondly, Islamic banks do not generate profits from interest because they use halal contracts in accordance with Islamic principles and have sufficient assets to protect their financing risks (Research\&Markets, 2020).

Some of these facts and data indicate that Islamic banking has a major contribution in the development of the global Islamic financial market as well as being a financial institution that is made as a comparison with conventional banking, especially in the development of service products. Islamic banks have different characteristics from conventional banks because they do not rely on interest as an instrument to determine the price of services. Islamic banks have operational concepts that use various sharia transaction schemes such as buying and selling (murabahah, salam, and istishna), profit sharing (mudharabah and musyarakab), and leasing (ijarah and ijarah muntabiya bittamlike). Therefore, Islamic banks need multitalented human resources because the risk management of each type of transaction scheme is also not the same between one another (Nawaz, 2019).

Several previous studies have shown that human resource is an accelerator of a company's excellence, especially in improving company performance (Morris, Alvarez, Berney, \& Molloy, 2017; Subramony, Krause, Norton, \& Burns, 2008; Wang, He, \& Mahoney, 2009). The complexity of Islamic banking operational activities certainly requires superior human resources obtained from the process of recruitment, internal coaching, training, and tiered assignments which certainly requires a high investment. Investment in the field of human resource development is the company's strategy to maintain its presence in the market and efforts to keep abreast of external factors that may directly or indirectly affect the company's performance (Aziz, 2017; Zarrouk, Ben Jedidia, \& Moualhi, 2016; Nor Izzati, 2017; Zarrouk et al., 2016). Therefore, Islamic banking needs to periodically evaluate the impact of this investment in human resources on its financial and nonfinancial performances.

Islamic banking performance is also influenced by the structure and mechanism of corporate governance because it can help in minimizing institutional problems such as the potential for error, fraud and moral hazard in the management of Islamic banks (Sulub, Salleh, \& Hashim, 2020). Islamic banking organizational structure has different characteristics from conventional banks with the Sharia Supervisory Board (SSB) which has a role to oversee aspects of commitment to the fulfillment of Sharia compliance and Islamic ethical values (Najwa, Ramly, \& Haron, 2019). This research fills a research gap in investigating the nexus of intellectual capital and corporate governance mechanism on Islamic banking performance which has not been discussed in previous papers, particularly using Islamic banking in several countries that are committed to develop the Islamic financial industry.

Based on the description above, this study aims to examine the relationship of Islamic banking performance with intellectual capital and the governance structure of Islamic banking. This research will continue the approach used by Ibrahim, Khong, Abdullah, \& Amir (2019) in measuring financial performance, Pulic (1998) in measuring the strength of intellectual capital, and Rahman \& Bukair (2013) in examining the contribution of SSB in Islamic banking activities. This paper will be divided into several parts of the discussion: First, it discusses the performance of Islamic banking, intellectual capital, and organizational governance structures in Islamic banking. Second, it discusses the formulation of hypotheses. Third, it discusses the research methodology, the results of statistical testing and discussion. Finally, this paper will conclude with conclusions, suggestions, and recommendations for the management of Islamic banks, competent regulators, and future researchers.

\section{The Performance of Islamic Banks}

Islamic banking is seen as a financial institution that puts ethics in its operational activities so that its character will reflect the values of moral superiority and social responsibility in its operational activities (Berger, Boubakri, Guedhami, \& Li, 2019). This is certainly driven by Islamic values that 
become its operational guidelines such as the prohibition of usury, gharartransactions, and investing in prohibited sectors such as alcohol, cigarettes, and arms trade (Drissi \& Angade, 2019).

Islamic banking uses two product approaches, namely: equity-based financing and debtbased financing. Although using these two approaches, Islamic banks always emphasize the quality of assets used as a basis for conducting transactions. Therefore, Islamic banking in general has a relatively lower risk compared to conventional banks because it has an advantage in the quality of its assets (Narayan \& Phan, 2019). Optimizing the use of productive assets in the distribution of financing will generate revenue that contributes to the profit of Islamic banking. With efficiency efforts in the use of operational expenses, Islamic banks will continue to produce optimal profits.

This profit is usually used as an indicator of the financial success of Islamic banking in the aspect of profitability (Zarrouk et al., 2016). Islamic banking profitability can be measured by Return on Assets (RoA) as previously studied by Cihák \& Hesse (2008) using 20 Islamic banks in the world and found that RoA is influenced by the capital and the debt factors compared to each of its assets. Another financial aspect of external factors that affect profitability is shown by the study of Wasiuzzaman \& Tarmizi (2010) which concludes that Gross Domestic Product (GDP) and inflation have a positive relationship with profitability.

Besides financial factors, there are also non-financial factors such as corporate governance that can affect the profitability of Islamic banking. Ibrahim et al. (2019) examined the effect of corporate governance mechanisms on financial performance of conventional and Islamic banks in Malaysia in 2009 - 2015. They found that one of the determinants was the independent director variable on the efficiency of Islamic banks. Meanwhile, the CEO's gender composition is found to have an effect on the profitability, solvency, and efficiency of conventional banks. Nomran \& Haron (2020) examined the effect of SSB measures on the performance of Islamic banking in several countries. As a result, the most optimal SSB size results on the performance of Islamic banking is 5 (five) members. This provides a recommendation to the Accounting and Auditing Organization for Islamic Financial Institutions (AAOIFI) to revise the SSB qualification standards that only provide a minimum SSB limitation of 3 (three) members. Some of the references above show that the performance of Islamic banking can be influenced by many factors, both financial and non-financial factors and includes factors that originate from internal and also external part of Islamic banking.

\section{Intellectual Capital of Islamic Banks}

Intellectual capital is a very important aspect for the development of Islamic banking. This is because Islamic banking has a more complex character than conventional banking, so it requires more competent human resource competence to complete various works in Islamic bank. Nawaz (2019) examined the relationship between intellectual capital and corporate governance on the performance of Islamic banking in 47 Islamic banks in the period of 2005 - 2010. The study used the market value of Islamic banks as measured by Tobin's Q formula as the dependent variable which was then tested by looking at the effect of disclosure of the Human Capital Index (HCI) and several corporate governance variables such as the number of BOD members, the number of SSB members, the strength of the CEO, the proportion of independent directors, and the number of audit committee members. This study used a period divided into three phases, namely before, during, and after the financial crisis in 2008. This study found that intellectual capital helps Islamic banks to maintain their performance before and after the financial crisis.

On the other hand, intellectual capital is associated with a company's ability to create, implement, and measure its intangible resources to increase value that will later improve company performance (Dean \& Kretschmer, 2007). Most researchers agree that intellectual capital is a multidimensional concept used to describe intangible assets (Buallay, 2019). However, the measurement of intellectual capital has not been determined absolutely. Pulic (1998) found a method for measuring intellectual capital, namely the Value Added Intellectual Capital (VAIC TM) method. There are several main components in the model developed by Pulic (1998), namely Value Added Capital Employed (VACA), Value Added Human Capital (VAHU), and Structural Capital Value Added (STVA). 
When measuring the main components of intellectual capital, there are several previous studies that found a significant and positive relationship. Ozkan et al. (2017) who examined banks in Turkey found that the main components of VAIC ${ }^{\text {TM }}$ had an influence on financial performance. Another supporting study is Ismail \& Karem (2011) who examined the effect of intellectual capital on financial performance in Bahrain in the period of 2005 - 2007 showed significant results. Moreover, research conducted by Buallay (2019) and Al-Musali \& Ismail (2014) show that intellectual capital has a significant positive effect on financial performance. This study also uses the intellectual capital to measure its effect on the performance of Islamic banking.

\section{Corporate Governance Mechanism of Islamic Banks}

Corporate governance in Islamic banking departs from an understanding of the concept of dualism of accountability in the Islamic concept of accountability to God since God is the creator and the preserver of the universe and accountability to human beings and the environment (Rahman \& Bukair, 2013). All Muslims have a responsibility in carrying out their lives in the world which will be accounted for in the hereafter. Therefore, Islamic business entities, including Islamic banking, are required to carry out all the commands of Allah and stay away from their prohibitions in carrying out their operational activities. With this consequence, the mechanism of corporate governance in Islamic banking is certainly different from conventional banking because there will be several functions devoted to ensuring the implementation of governance that meets Islamic principles (Noordin \& Kassim, 2019).

The establishment of SSB is one of the differentiators of governance of Islamic banking with conventional banking because SSB has a very important role to provide guidance and to formulate sharia opinions related to products and services offered in accordance with sharia principles. Farook, Hassan, \& Lanis (2011) revealed that the presence of SSB in Islamic banking would be able to improve the quality of internal supervision in the field of sharia compliance. SSB can also increase the commitment of Islamic bank's management to encourage the creation of social justice values for its stakeholders (Safieddine, 2009). Moreover, research conducted by Darwanto \& Chariri (2019) and Rahman \& Bukair (2013) supports these results. The establishment of SSB is not to hamper the management of Islamic banks to make a profit, but rather to align the management of Islamic banks to get profits in the right and lawful way.

On the other hand, the benefits of Islamic banks can be obtained through governance mechanisms that run optimally by involving all elements of management and supervisors in realizing the objectives of Islamic banking. The profitability of a bank can be influenced by the existence of independent directors. This is worthy of special scrutiny because of its important position in the corporate governance mechanism and representing all minority shareholders (Rowe, Shi, \& Wang, 2011). Therefore, an increase in the number of independent directors will lead to an improved company performance. Ghaffar (2014) clarifies that there is a positive relationship between the independence of the board and the profitability of Islamic banks in Pakistan. When the number of independent directors on the board increases, the profitability (ROA) of the bank will also increase due to the efficiency of the board (Ibrahim et al., 2019).

Academic directors are directors who have a high educational background and also have professional qualifications or certifications that can be used as a reference in decision making. Academic directors have competence in the fields they master so that they are expected to contribute to the company's performance. Research conducted by Francis, Hasan, \& Wu, (2015) compared the characteristics of corporate governance between academic directors and external non-academic directors. The research revealed that academic directors were more likely to be present in the directors' meeting than other directors. The results also indicated that academic directors performed better than other outside directors. Tian \& Ming Lau (2001) conducted a study to examine the influence of academic directors on financial performance. The results of the study stated that academic directors had a positive and significant effect on company performance (ROA). By having business and economic knowledge, members of the board are expected to have better ability to manage business and make business decisions. 
Based on the literature review above, this study will examine the relationship between intellectual capital and corporate governance mechanisms on the performance of Islamic banking as described in Figure 2 below.

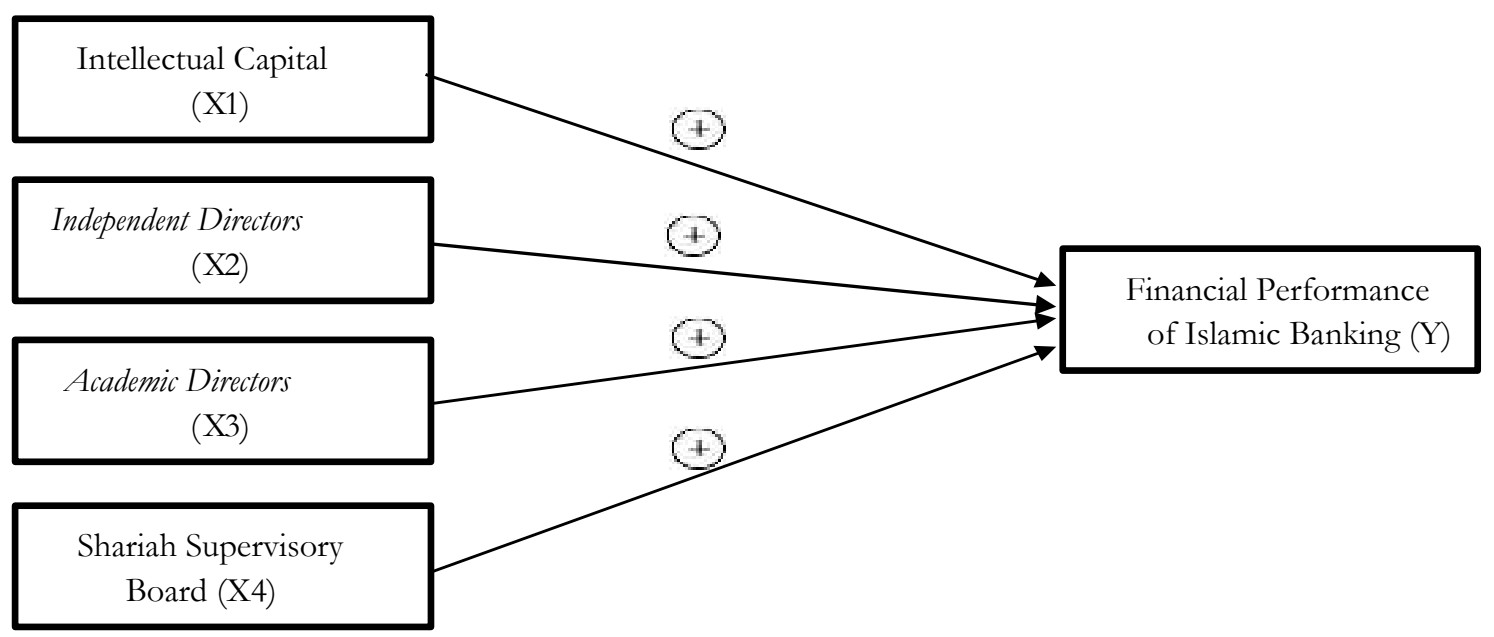

Figure 2. Hypotheses Framework

\section{Literature Review and Hypotheses Development}

\section{The Relationship between Intellectual Capital to Islamic Bank Financial Performance}

Management of companies with professionals who are more aware of the conditions in running business is very important based on the concept of Agency Theory. Competitive advantage is an advantage that must be owned by a company in order to win the competition in one industry. This can be achieved if the company has professionals who are ready to manage the company. If the company can manage and utilize the potential possessed by employees properly, the company can minimize costs efficiently in order to increase the profits of the company that is managed by the company's professional staff.

Previous research conducted by Ozkan et al. (2017) who examined banks in Turkey stated that the components of VAIC significantly influenced company performance. The study examined 44 Islamic banks in Turkey as a sample with 3 components of the VAIC as an independent variable with financial performance as the dependent variable. The result is that some components of VAIC have an influence on the financial performance of Islamic banking in Turkey. By using the VAIC TM model formulated by Pulic (1998) as a measure of a company's intellectual abilities, the following hypothesis is formulated:

H1: Intellectual Capital has a positive effect on the financial performance of Islamic banking

\section{The Relationship between the Composition of Independent Directors and the Financial Performance of Islamic Banks}

Differences in interests often lead to conflicts between management (agents) and company owners (principals). To align the company's goals, the interests of the company's owners, and the interest of management, it requires an independent, neutral or impartial top-level management. The independent director is a person who can guarantee the stability of two interests in the company. In general, the company has a goal to achieve maximum profit. It contains the concept that companies must carry out activities effectively and efficiently. Effective is related to the targeted objectives to be achieved, while efficient is about the minimum cost possible to achieve these goals (Harjito \& Martono, 2010).

Previous research conducted by Tian \& Lau (2001), the proportion of independent directors did not have a significant relationship to ROA despite having a positive relationship. The independent director is expected to be able to maintain company stability and to involve in 
decision-making so that the company can achieve maximum profits. Based on the description above, the following hypothesis is proposed:

H2: Independent Director has a positive effect on the financial performance of Islamic banking

\section{The Relationship between Academic Directors and the Financial Performance of Islamic Banks}

The board of directors is the beginning of the implementation of the company's strategy to achieve the company's goals, to achieve maximum profits. Professionals must be supported by a high educational background and other professional qualifications that can support the quality of decision making. Academic directors are directors who have a high educational background and also have professional qualifications or certifications that can be used as a reference in decision making. In addition, based on a corporate governance perspective, academic directors are organizational governance functions that are able to provide reinforcement in the system because they work more systematically with scientific procedures based on scientific data and facts so that they will contribute to a strong and robust decision making. They have different points of view in assessing problems than non-academics and can give different perspective in the meeting, so it can provide a diversity of opinions (Francis et al., 2015).

Based on previous research conducted by Tian \& Lau (2001), this research examines the various kinds of effects of academic directors on various elements in the company, one of which is the company's performance which is proxied by ROA. The results of the study stated that academic directors had a positive and significant effect on company performance (ROA). Therefore, by having business and economic knowledge, board members would have better ability to manage business and make business decisions. Based on the description above, the following hypothesis is proposed:

H3: Academic directors on Islamic banking have a positive effect on the performance of Islamic banking

\section{The Relationship between Sharia Supervisory Board (SSB) and the Financial Performance of Islamic Banks}

Institutions that operate according to sharia principles must be monitored so they are always in accordance with sharia principles. Islamic banking must have an internal body that has the authority to supervise and make decisions regarding company compliance with sharia principles. SSB has a very important role because the council has the responsibility to provide guidance to Islamic banking and to establish rules and regulations in accordance with sharia principles and rules (Darwanto \& Chariri, 2019). Farook et al. (2011) revealed that the presence of SSB might increase supervision. In addition, based on corporate governance perspective, SSB is a function in the governance of an Islamic banking organization that have knowledge of sharia as well as contemporary Islamic finance so that they are able to provide advice and recommendations on actions to be taken by management to produce halal profits based on Islamic values without violating Islamic principles that become an important character of Islamic banking. Based on previous research conducted by Farook et al. (2011), the study examined the effect of SSB on CSR disclosure. The results of the study stated that the SSB had a positive and significant influence on the disclosure of the CSR of the sharia banking company. Some characteristics of SSB may influence the effectiveness of the SSB's role. The aim of companies that want to achieve maximum profits with compliance with sharia principles in every activity can cause shifts and changes in the company's system. Based on the description above, the following hypothesis is proposed: $\mathrm{H} 4$ : SSB characteristics have a positive effect on the financial performance of Islamic banking

\section{Research Method}

The population used in this study is Islamic banking in the world during 2013-2017 which received the award of the "Best Islamic Financial Institution 2018 Award" (Global Finance Magazine, 2018). There are 26 Islamic banks in the world which are located in various countries. Meanwhile, this 
study uses purposive sampling based on certain criteria, including the following: (a) Islamic banking in the world that received the Best Islamic Financial Institution 2018 award; (b) Islamic banks publish periodic financial statements in the period of 2013-2017 through the official website of each bank. Based on the sample selection criteria above, there is a total sample of 20 Islamic banks, as follows:

Table 1. The Sample of Islamic Banks

\begin{tabular}{cll}
\hline No. & \multicolumn{1}{c}{ Name of Islamic Bank } & \multicolumn{1}{c}{ Country of Origin } \\
\hline 1. & Afghanistan International Bank & Afganistan \\
2. & Banque Al Baraka D' Algerie & Algeria \\
3. & Al Baraka Bank Bahrain & Bahrain \\
4. & Islami Bank Bangladesh & Banglades \\
5. & Bank Islam Brunei Darussalam & Brunei Darussalam \\
6. & Abu Dhabi Islamic Bank Egypt & Mesir \\
7. & Bank Muamalat & Indonesia \\
8. & Jordan Islamic Bank & Jordan \\
9. & Al Hilal Bank & Kazakstan \\
10. & Boubyan Bank & Kuwait \\
11. & Maybank Islamic & Malaysia \\
12. & Jaiz Bank & Nigeria \\
13. & Meethaq Islamic Banking & Oman \\
14. & Meezan Bank & Pakistan \\
15. & Qatar Islamic Bank & Qatar \\
16. & Al Rajhi Bank & Arab Saudi \\
17. & HBZ Bank & Afrika Selatan \\
18. & Amana Bank & Sri Lanka \\
19. & Kuveyt Turk Katilim Bankasi & Turki \\
20. & Emirates Islamic & Uni Emirat Arab \\
\hline & & Total \\
\hline Source & banks \\
\hline
\end{tabular}

Source: (Global Finance Magazine, 2018) modified

The dependent variable of this study is the performance of Islamic banking as measured by profitability ratio. The profitability ratio used is RoA (Return on Assets). While the independent variables in this study, such as intellectual capital are calculated by the VAIC ${ }^{\text {TM }}$ formula designed by Pulic (1998) to measure the performance of intellectual capital in companies. Meanwhile, another independent variable in the form of an independent director is calculated by making the division between the number of independent directors divided by the number of its board of directors. Furthermore, the independent variable academic directors are measured by counting the number of directors with a minimum Master (S2) degree and directors who have professional certification or according to their scientific fields. The last independent variable measured was the characteristics of the SSB as measured by Rahman \& Bukair (2013) but with modifications according to the context of this study as follows:

Table 2. Scoring of SSB's Characteristics

\begin{tabular}{|c|c|c|}
\hline No. & Components & Method of calculation \\
\hline 1. & The existence of SSB & If any $=1$, If not any $=0$ \\
\hline 2. & Number of SSB & $\begin{array}{l}\text { If it has } 5 \text { members or more }=1 \text {, If only has }< \\
5 \text { members }=0\end{array}$ \\
\hline 3. & Member of SSB that has cross membership & $\begin{array}{l}\text { If it has cross membership in other institutions } \\
=1 \text {, if has no cross membership }=0\end{array}$ \\
\hline 4. & Member of SSB that has doctoral qualification & $\begin{array}{l}\text { If it has doctoral/professorship qualification }= \\
1 \text {, If it has no doctoral/professorship }=0\end{array}$ \\
\hline 5. & Member of SSB that has international reputation & $\begin{array}{l}\text { If it has membership in AAOIFI }=1 \text {, If it has } \\
\text { no membership in AAOIFI }=0 \text {. }\end{array}$ \\
\hline & Total Score & 0 to 5 \\
\hline
\end{tabular}


Testing the hypothesis of this study using multiple linear regression data analysis through Eviews 9 software, with the following mathematical equation:

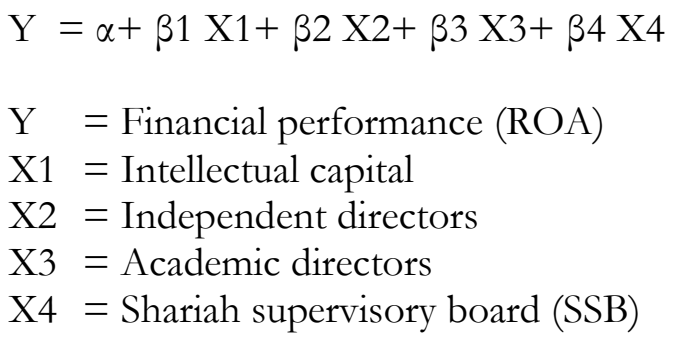

\section{Results and Discussion}

\section{Descriptive Analysis}

Data is taken from 20 Islamic banks that meet the criteria previously determined. The data in table 3 shows descriptive statistical data for each variable based on minimum and maximum values, mean, and standard deviation. Financial performance as the dependent variable has a minimum value of 0.0006 and a maximum value of 0.1 . Intellectual capital as independent variable has a minimum value of 4.0583 and a maximum value of 11.089 , with an average of 6.5075 and a standard deviation of 1.4088 .

Independent director has a minimum value of 0 and a maximum value of 0.6667 , with an average of 0.2223 and a standard deviation of 0.2554 . The academic directors as independent variable has a minimum value of 0 and a maximum value of 0.1 , with an average of 0.4165 and a standard deviation of 0.3067 . The SSB as independent variable has a minimum value of 0 and a maximum value of 0.5 , with an average of 2.2162 and a standard deviation of 1.7222 .

Table 3. Descriptive Statistics

\begin{tabular}{llrrrr}
\hline \multicolumn{1}{c}{ Variable } & N & Minimum & Maximum & \multicolumn{1}{c}{ Mean } & Std. Deviation \\
\hline Intellectual capital & 100 & 4.0583 & 11.089 & 6.5075 & 1.4088 \\
Independent directors & 100 & .0 & .6667 & .2223 & .2554 \\
Academic directors & 100 & .0 & .1 & .4165 & .3067 \\
Shariah supervisory board (SSB) & 100 & .0 & .5 & 2.2162 & 1.7222 \\
Financial performance & 100 & .0006 & .0239 & .0113 & .0051 \\
Valid N (listwise) & & & & & \\
\hline
\end{tabular}

Source: Output from Eviews 9 (2019)

After the classic assumption test was done, the next step is to do a multiple linear regression test. This analysis model is used to determine the effect of intellectual capital variable (X1), independent directors (X2), academic directors (X3), and sharia supervisory boards (X4) on the financial performance $(\mathrm{Y})$ of Islamic banking. After determining regression estimation model, this paper uses random effect model. From the results of the multiple linear regression analysis test contained in table 4 , the multiple regression equation is as follows:

$$
\mathrm{ROA}=0.00695+0.000794 \mathrm{X}_{1}-0.001296 \mathrm{X}_{2}+0.001134 \mathrm{X}_{3}-0.000377 \mathrm{X}_{4}
$$

Based on this equation, it can be explained that only intellectual capital variable that have a significant positive effect on financial performance (ROA). This means that if the company can manage intellectual capital owned properly, it will improve the financial performance of Islamic banking. However, variables other than intellectual capital simultaneously have no effect on financial performance. This is because independent directors, academic directors, and sharia supervisory boards have no significant effect on financial performance at alpha $5 \%$.

In accordance with Table 5, it is known that the amount of financial performance influenced by intellectual capital, independent directors, academic directors, and sharia supervisory 
boards is $2.9 \%$. This shows that $98.1 \%$ of financial performance is influenced by other variables outside the model.

Table 4. Multiple Regression Analysis

\begin{tabular}{lccc}
\hline \multicolumn{1}{c}{ Model } & Coefficient & T & Sig \\
\hline (Constant) & .006950 & 2.306 & .0241 \\
Intellectual capital & .000794 & 2.104 & .0390 \\
Independent directors & -.001296 & -0.595 & .5532 \\
Academic Director & .001134 & 0.567 & .5724 \\
Shariah supervisory board (SSB) & -.000377 & -0.897 & .3724 \\
\hline
\end{tabular}

Source: Output from Eviews 9 (2019)

Tabel 5. Determination Coefficient

\begin{tabular}{ccc}
\hline $\mathrm{R}$ & R Square & Adjusted R Square \\
\hline & 0,083 & 0,029 \\
\hline
\end{tabular}

Source: Output from Eviews 9 (2019)

\section{The Impact of Intellectual Capital and Corporate Governance to Islamic Bank Financial Performance}

Intellectual capital is associated with the ability of companies to create, implement, and measure intangible resources in order to create value, which can improve the ability of company operation and performance (Dean \& Kretschmer, 2007). However, today the definition of intellectual capital refers to intellectual material, knowledge, experience, intellectual property, and information that can be included to create value (Dumay, Guthtrie, \& Puntillo, 2015).

Islamic banks require human resources with superior intellectual capital quality. This is due to the complexity of the Islamic banking business, which starts with the formulation of a contract concept according to customer needs. This is certainly different from conventional banks which have a single contract structure using an interest instrument. Islamic banks have various contract structures, ranging from buying and selling, business cooperation, rental services for goods and benefits. Guided with the restrictions from Islamic principles that must always be met as well as competition with other financial institutions, this certainly requires that the human resources in Islamic banks have a multitalented character and quickly adapt to technological and market developments.

Therefore, intellectual capital is the answer to the need for human resource competencies in Islamic banks. Superior intellectual capital can only be obtained by starting a rigorous selection process with sufficient criteria so that a candidate for Islamic bank management has good basic qualifications to be formed as a strong leader of Islamic banks. Furthermore, the process in Islamic banking needs to be prepared with a structured human resource development program including expertise in the field of figh muamalah, contemporary skills on Islamic banking and finance, and expertise in communication as well as good market knowledge.

If these things can be done by the management of Islamic banks, then the aim of Islamic banks to realize the ideals of Islamic economy to create prosperity and justice will have the prospect of being realized. More specifically, intellectual capital has a significant positive effect on financial performance. This research shows that Islamic banking in the world has managed its resources well by professional staff. Thus, this research provides evidence that intellectual capital contributes greatly to the development of Islamic bank organizations. This is in line with the intellectual capital approach which explains that intellectual capital is essential asset in making and maintaining company's competitive advantage (Grant, 1996). This also confirms that intellectual capital contributes to Islamic banks, especially in increasing organizational competitiveness because they have qualified human resources in solving the complexities of Islamic banking business into a pattern capable of forming strength for Islamic banks to generate optimal profits for Islamic banks.

Moreover, Islamic banks have more business complexity than conventional banking. The complexity of the business is reflected starting from contracts based on sharia transactions, both 
with the pattern of buying and selling, profit sharing, leasing, and several service contracts to the implementation of these contracts (Al Rahahleh, Ishaq Bhatti, \& Najuna Misman, 2019). In addition, the business risks faced by the management of Islamic banks also require extensive knowledge about comprehensive risk management. This certainly requires the existence of superior quality human resources with high competence. Therefore, the human resources they have can increase the value added of the company, which in turn will affect the financial performance of Islamic banking, which is proxied by Return on Assets. Ismail \& Karem (2011), Razak et al. (2016), Ozkan et al. (2017), and Buallay (2019) support the results of this study.

Independent director is a neutral party so that the company's goals, owner's interests, and management's performance can run in harmony. An independent director is a person who can guarantee stability between two interests in the company. The important role held by independent directors is the supervisor of activities so that the policies made can be implemented optimally in the company. Therefore, they will contribute in terms of their experiences to be a lesson for the development of the organization of Islamic banks. The independent directors will be wiser in giving consideration to management who usually tend to be progressive and less careful in making decisions just because it is oriented towards increasing business profits. Independent directors are more careful because they feel that the most important thing in Islamic banking is stability and the company's ability to survive in the long term. Thus, research shows that independent directors have no significant positive effect on financial performance. It can be concluded that the high or low percentage of independent directors has no impact on financial performance. Because in practice, an independent director will participate in supervision but will not have an impact on company performance. Tian \& Lau (2001), Kusumastuti \& Sastra (2005), Aldalayeen (2017), Riyadi \& Santoso (2018), and Ibrahim et al., (2019) support the results of this study.

Academic directors are educational qualifications held by the board of directors. Directors who have high educational qualifications shows a unique character compared to other directors. Academic directors who have competence in the fields they master are expected to contribute to company performance. However, research shows that academic directors do not have a significant positive effect on financial performance. This is because the number of boards of directors who have higher education or professional certification only adds to the level of supervision and planning. However, this does not affect the operational performance of Islamic banking. The results of this study differ from studies conducted by Francis et al. (2015) because the results of this study use the scoring method to count the number of boards of directors who have a master's degree and a board of directors who have professional certification.

Islamic banking has a different governance structure than conventional banking (Rahman \& Bukair, 2013). Islamic banking has SSB which has the function to oversee the compliance of sharia entities related to business operations. According to AAOIFI standards, SSB is entrusted with tasks that lead to revising and monitoring sharia bank transactions one by one to ensure these transactions are in accordance with Sharia principles (AAOIFI, 2018). Normally, the orientation of SSB and management of Islamic banks is indeed different in looking at the objectives of Islamic banks. Islamic bank management will continue to prioritize profit orientation which is increasing nowadays. While SSB has an orientation to maintain sharia compliance and does not specifically evaluate the performance of management in achieving business profits. Therefore, the results of this study confirm that SSB can actually result in a decrease in operating profit because SSB will be more stringent in overseeing sharia compliance which will sometimes be related to the achievement of operating profit. For example, the management of an Islamic bank wants business expansion in the form of financing certain sectors which are profitable but Islamically doubtful. SSB will tend to take steps to avoid things that are in doubt so that sometimes it will eliminate the potential business profits to be obtained by management. Therefore, in line with the explanation above, then this study cannot prove the effect of SSB on financial performance. The SSB only oversees the company's adherence to Islamic law and not to make decisions related to matters relating to company performance. This is supported by Eksandy (2018) who showed that SSB has no significant effect on financial performance because SSB in a bank has multiple SSB positions in other banks. Thus, the SSB's performance is considered less influencing the banking performance. 


\section{Conclusions}

The results show that the measurement of intellectual capital with the VAIC TM model had a significant positive effect on financial performance (ROA). Meanwhile, the independent director, academic directors, Sharia Supervisory Board did not significantly influence financial performance (ROA). Based on the results of research, important implications in the context of the industry practice, among others, is the need for attention of Islamic bank management to take care of its intellectual capital. Management needs to allocate its resources to provide guidance and development of human resources through regular training in the field of fiqh muamalah, contemporary Islamic banking products and services, effective business communication, as well as extensive market knowledge to anticipate the competition in ways that are in accordance with the principles of sharia.

Although this research has successfully tested the effect of intellectual capital on financial performance (ROA), this research has not been able to test the influence of independent directors, academic directors, and sharia supervisory boards. The independent director variable and the sharia supervisory board only present quantity but not quality. Future studies can measure these variables by looking at quality, such as academic qualifications, frequency of meeting attendance, and professional certification. In addition, quality measurements of academic directors can be developed by assessing the popularity of directors. Future studies are also expected to explore other variables because the variables used in this study can only explain the effect on financial performance by $3 \%$. Other variables that can be used such as company size, leverage, and capital structure.

Finally, this study has a limitation in using Islamic banking data from various countries with backgrounds that are certainly different from one another which might be bias. Therefore, further research can use a sample of each country with each own unique characteristics so that human resource development models can be evaluated with the most effective models to be able to generate optimal profits for Islamic banks by complying to Islamic principles.

\section{Author Contributions}

Conceptualization: Rifqi Muhammad

Data Curation: Muhammad Aldino Mangawing

Formal Analysis: Muhammad Aldino Mangawing

Investigation: Rifqi Muhammad

Methodology: Selfira Salsabila

Project Administration: Selfira Salsabila

Supervision: Rifqi Muhammad

Validation: Rifqi Muhammad

Visualization: Selfira Salsabila

Writing - original draft: Muhammad Aldino Mangawing

Writing - review \& editing: Rifqi Muhammad

\section{References}

AAOIFI. (2018). Accounting and Auditing Standards for Islamic Financial Institutions. Manama: AAOIFI.

Al-Musali, M. A. K., \& Ismail, K. N. I. . (2014). Intellectual capital and its effect on financial performance of bank: evidence from Saudi Arabia. Procedia-Social and Behavioral Scineces, 164, 201-207. https://doi.org/10.1016/j.sbspro.2014.11.068

Al Rahahleh, N., Ishaq Bhatti, M., \& Najuna Misman, F. (2019). Developments in risk management in islamic finance: a review. Journal of Risk and Financial Management, 12(1), 122. https://doi.org/10.3390/jrfm12010037

Aldalayeen, B. (2017). Does corporate governance affect the financial performance? analysis of 
findings from Jordanian banks. International Journal of Business and Management, 12(4), 123129. https://doi.org/10.5539/ijbm.v12n4p123

Aziz, N. I. M. (2017). Islamic banking profitability: roles played by internal and eksternal banking factors. Journal of Muamalat Islamic Finance Research, 14(1), 23-38. https://jmifr.usim.edu.my/index.php/jmifr/article/view/12

Berger, A. N., Boubakri, N., Guedhami, O., \& Li, X. (2019). Liquidity creation performance and financial stability consequences of Islamic banking: evidence from a multinational study. Journal of Financial Stability, 44, 1-18. https://doi.org/10.1016/j.jfs.2019.100692

Buallay, A. (2019). Intellectual capital and performance of Islamic and conventional banking: empirical evidence from Gulf Cooperative Council countries. Journal of Management Development, 38(7), 518-537. https://doi.org/10.1108/JMD-01-2019-0020

Cihák, M., \& Hesse, H. (2010). Islamic banks and financial stability: an empirical analysis. Journal of Financial Services Research, 38(2), 95-113. https://doi.org/10.1007/s10693-010-0089-0

Darwanto, \& Chariri, A. (2019). Corporate governance and financial performance in Islamic banks: the role of the sharia supervisory board in multiple-layer management. Banks and Bank Systems, 4(4), 183-191. http://dx.doi.org/10.21511/bbs.14(4).2019.17

Dean, A., \& Kretschmer, M. (2007). Can ideas be capital? factors of production in the postindustrial economy: a review and critique. Academy of Management Review, 32, 537-594. https://doi.org/10.5465/amr.2007.24351866

Drissi, S., \& Angade, K. (2019). Islamic financial intermediation the emergence of a new model. European Journal of Islamic Finance, 12, 1-7. https:/ / doi.org/10.13135/2421-2172/2880

Dumay, J., Guthtrie, J., \& Puntillo, P. (2015). IC and public sector: a structured literature review. Journal of Intellectual Capital, 16(2), 267-284. https://doi.org/10.1108/JIC-02-2015-0014

Eksandy, A. (2018). Pengaruh good corporate governance terhadap kinerja keuangan pada perbankan syari'ah Indonesia. Jurnal Akuntansi, 5 (1), 1-10. https://doi.org/10.30656/jak.v5i1.498

Farook, Sayd, Hassan, M. K., \& Lanis, R. (2011). Determinants of corporate social responsibility disclosure $\square$ : the case of islamic banks. Journal of Islamic Accounting and Business Research, 2(2), 114-141. https://doi.org/10.1108/17590811111170539

Francis, B., Hasan, I., \& Wu, Q. (2015). Professors in the boardroom and their impact on corporate governance and firm performance. Financial Management, 44(3), 547-581. https://doi.org/10.1111/fima.12069

Ghaffar, A. (2014). Corporate governance and profitability of islamic banks operating in Pakistan. Interdisciplinary Journal of Contemporary Research in Business, 6 (2), 320-336. https://journalarchieves37.webs.com/320-336jun14.pdf

Global Finance Magazine. (2018). World's best islamic financial institution awards 2018: table of winners. Global Finance Magazine. Retrieved form https://www.gfmag.com/magazine/may-2018/worlds-best-islamic-financial-institutions2018-global-winners

Grant, R. M. (1996). Toward a knowledge-based theory of the firm. Strategic Managmeent Journal, 17, 109-122. https://doi.org/10.1002/smj.4250171110

Harjito, A., \& Martono. (2010). Manajemen Keuangan. Yogyakarta: Ekonisia.

Ibrahim, H., Khong, J., Abdullah, Z., \& Amir, A. (2019). Corporate governance mechanisms and financial performance $\square$ : a comparative study between local islamic banks and local conventional banks in Malaysia. Islamic Development Management, 75-104. https://doi.org/10.1007/978-981-13-7584-2 
IFSB. (2018). Islamic Financial Services Industry Stability Report. Kuala Lumpur, Malaysia. Retrieved form https://www.ifsb.org/sec03.php

Ismail, K. N. I. K., \& Karem, M. A. (2011). Intellectual capital and financial performance of banks in Bahrain. Journal of Business Management and Accounting, 1(1), 63-77. http:/ /www.ejournal.uum.edu.my/index.php/jbma/article/view/6794

Kusumastuti, S., \& Sastra, P. (2005). Pengaruh board diversity terhadap nilai perusahaan dalam perspektif corporate governance. Jurnal Akuntansi Dan Keuangan, 9(2), 88-98. https://doi.org/10.9744/jak.9.2.pp.\%2088-98

Morris, S. S., Alvarez, S. A., Berney, J. B., \& Molloy, J. C. (2017). Firm-specific human capital investments as a signal of general value: revisiting assumptions about human capital and it is managed. Strategic Management Journal, 38(4), 912-919. https://doi.org/10.1002/smj

Najwa, N. A., Ramly, Z., \& Haron, R. (2019). Board size, chief risk officer and risk-taking in islamic banks: role of shariah supervisory board. Jurnal Pengurusan, 57. https://doi.org/10.17576/pengurusan-2019-57-01

Narayan, P. K., \& Phan, D. H. B. (2019). A survey of Islamic banking and finance literature: Issues, challenges and future directions. Pacific Basin Finance Journal, 53, 484-496. https://doi.org/10.1016/j.pacfin.2017.06.006

Nawaz, T. (2019). Exploring the nexus between human capital, corporate governance and performance: evidence from islamic banks. Joumal of Business Ethics, 157(2), 567-587. https://doi.org/10.1007/s10551-017-3694-0

Nomran, N. M., \& Haron, R. (2020). Shari'ah supervisory board's size impact on performance in the Islamic banking industry: An empirical investigation of the optimal board size across jurisdictions. Journal of Islamic Accounting and Business Research, 11(1), 110-129. https://doi.org/10.1108/JIABR-05-2017-0070

Noordin, N. H., \& Kassim, S. (2019). Does shariah committee composition influence shariah governance disclosure?: evidence from Malaysian Islamic banks. Journal of Islamic Accounting and Business Research, 10(2), 158-184. https://doi.org/10.1108/JIABR-04-20160047

Ozkan, N., Cakan, S., \& Kayacan, M. (2017). Intellectual capital and financial performance: A study of the Turkish Banking Sector. Borsa Instanbul Review, 17 (3), 190-198. https://doi.org/10.1016/j.bir.2016.03.001

Pulic, A. (1998). Measuring the Performance of Intellectual Potential in Knowledge Economy. 2nd Mc Master World Congress on Measuring and Managing Intellectual Capital by Austrian Team for Intellectual Potential.

Rahman, A. A., \& Bukair, A. A. (2013). The influence of the shariah supervision board on corporate social responsibility disclosure by Islamic banks of Gulf Co-operation Council countries. Asian Journal of Business and Accounting, 6(2), 65-105. https://ajba.um.edu.my/article/view/2678

Razak, R. A., Mohammad, J., \& Tobiagi, S. M. (2016). Intellectual capital disclosures practices and intellectual capital performance in Saudi Arabia financial institution. Journal of Business Studies, 7(4), 1-14. http:// faratarjome.ir/u/media/shopping_files/store-EN-14858552299159.pdf

Research \& Markets. (2020). Global islamic finance market - growth, trends, and forecast (2018 - 2024). Research and Markets Retrieved form https://www.researchandmarkets.com/reports/4758280/global-islamic-finance-marketgrowth-trends

Riyadi, S., \& Santoso, C. B. (2018). The influence of board of commissioners, board of directors, 
board of commissioners independent audit committee and board of trustees to financial performance islamic banking (case study on islamic bank period in 2011-2013). Archives of Business Research, 6(5). https://doi.org/10.14738/abr.65.4568

Rowe, W., Shi, W., \& Wang, C. (2011). No TitleBoard governance and performance of Chinese banks. Banks and Bank. Systems, 6 (1). https://businessperspectives.org/images/pdf/

Safieddine, A. (2009). Islamic Financial Institutions and Corporate Governance: New Insights for Agency Theory. Corporate Governance: An International Review, 17 (2), 142-158. https://doi.org/10.1111/j.1467-8683.2009.00729.x

Standard\&Poor's. (2018). Islamic Finance Outlook 2018. S\&P Global Ratings. Retrieved form https://www.spratings.com/documents/20184/4521646/Islamic+Finance+2018+Digita 1-1.pdf/cf025a76-0a23-46d6-9528-cecde80e84c8

Subramony, M., Krause, N., Norton, J., \& Burns, G. N. (2008). No TitleThe relationship between human resource investments and organiza- tional performance: A firm-level examination of equilibrium theory. Journal of Applied Psychology, 93(4), 778. https://doi.org/10.1037/0021-9010.93.4.778

Sulub, S. A., Salleh, Z., \& Hashim, H. A. (2020). Corporate governance, SSB strength and the use of internal audit function by islamic banks: evidence from Sudan. Journal of Islamic Accounting and Business Research, 11(1), 152-167. https://doi.org/10.1108/JIABR-12-20160148

Tian, J. J., \& Lau, C. (2001). Board composition, leadership structure and performance in chinese. Asia Pasific Joumal of Management, 18(2), 245-263. https://doi.org/10.1023/A:1010628209918

Wang, H. C., He, J., \& Mahoney, J. T. (2009). Firm-specific knowledge resources and competitive advantage: The roles of economic and relationship based employee governance mechanisms. Strategic Management Journal, 30(12), 1265-1285. https://doi.org/10.1002/smj.787

Wasiuzzaman, S., \& Tarmizi, H. B. A. (2010). Profitability of Islamic banks in Malaysia: an empirical analysis. Journal of Islamic Economics, Banking and Finance, 6(4), 53-68. http://ibtra.com/pdf/journal/v6_n4_article3.pdf

Zarrouk, H., Ben Jedidia, K., \& Moualhi, M. (2016). Is Islamic bank profitability driven by same forces as conventional banks? International Journal of Islamic and Middle Eastern Finance and Management, 9(1), 46-66. https://doi.org/10.1108/IMEFM-12-2014-0120 